\title{
Interactive Learning Media for Cellular Communication Systems using the Multimedia Development Life Cycle Model
}

\author{
Hasanah Putri ${ }^{* 1}$, Iqbal Shadiq ${ }^{2}$, Gigin Gantini Putri ${ }^{3}$ \\ 1,2,3 Department of Telecommunication Engineering, Telkom University, Bandung, Indonesia
}

\begin{tabular}{|c|c|}
\hline Article Info & ABSTRACT \\
\hline Article history: & Based on the observations conducted to the students of Diploma of \\
\hline Received April 13, 2020 & Telecommunications Engineering Telkom University. It revealed that the \\
\hline Revised November 20, 2020 & processing and network optimization in the course of cellular communication \\
\hline Accepted December 03, 2020 & systems. It has resulted from the current learning media, which are only in \\
\hline Published June 15, 2021 & the form of textbooks and Powerpoint slides considered less attractive. \\
\hline Keywords: & $\begin{array}{l}\text { learning outcomes. In this study, an interactive learning media was designed } \\
\text { with the Multimedia Development Life Cycle (MDLC) method, Adobe Flash }\end{array}$ \\
\hline Action script 2.0 & professional CS6 software, using the action script 2.0 programming \\
\hline Adobe flash professional cs6 & $\begin{array}{l}\text { language. Learning media were designed according to users needs and } \\
\text { learning outcomes of cellular communication system courses. Based on the }\end{array}$ \\
\hline Cellular communication & testing results, the functionality showed $100 \%$ of features function as design \\
\hline systems & specifications. Meanwhile, the user satisfaction testing results obtained an \\
\hline Functionality testing & average MOS of 4.73 , which means that the learning media is classified \\
\hline Interactive learning media & great. Furthermore, based on the quantitative testing, the average value of \\
\hline Multimedia Development Life & Quiz after using this interactive learning media was 81 , which means that the \\
\hline Cycle (MDLC) & learning media can increase students' interest so that it affects the increase in \\
\hline Quantitative testing & \\
\hline
\end{tabular}

Corresponding Author:

Hasanah Putri,

Department of Telecommunication Engineering,

Telkom University Bandung,

Jl. Telekomunikasi Terusan Buah Batu Bandung 40257, Indonesia

Email: hasanahputri@tass.telkomuniversity.ac.id

\section{INTRODUCTION}

In this life, education plays a crucial role in improving and developing the quality of Human Resources (HR) [1]. The quality of education depends on how learning is implemented in schools. In this study, the case was the university, in which the subject matter delivered by the lecturers was not accepted by the students optimally. One of the reasons is the learning media used in the teaching and learning process.

In the implementation of teaching and learning, the quality learning media significantly influences the process and its results. The interactive learning media will increase student interest in learning and impact on learning outcomes improvements [2]-[4].

Interactive learning media serves to clarify the meaning of the message conveyed; therefore, it can achieve the learning objectives better and perfectly. Interactive learning media is the application of two or more media, including audio, text, graphics, pictures, and videos. Thus, the presentation is more exciting and enjoyable [5]-[8]. In addition to the motivation and interest of students, the interactive learning media can also help students improve the comprehension and get the information for fun [9]. Currently, the learning media used in the course of cellular communication systems include visualization using power points, videos (internal and external), discussion, and practicum. For some materials, the application of this material can attract students' interest in learning with a good grade indication. However, for the material of call processing and mobile network optimization, the application of this method was not significantly successful in attracting student learning that resulted in low levels of passing on this material. In the 2017/2018 and 2018/2019 school years, the average competency test scores for these two materials were 53.41 and 56.88 . 
Therefore, an interactive learning media was designed for the two materials. The media was designed using Adobe Flash Professional CS6 software [10]. This software can produce learning systems such as simulations and presentations that are interactive, communicative, and dynamic [11], [12]. It is in accordance with the needs of students and lecturers to improve the interest and learning outcomes of Diploma Telecommunications Engineering students. The discussion in this study includes the background of interactive learning media was built, then the methods used and the system design stages carried out, finally the results and the evaluations of conducted tests.

\section{METHOD}

The focuses of this study are to design interactive animation-based learning media and to evaluate the user satisfaction to use multimedia elements in the learning media. In this study, the Multimedia Development Life Cycle (MDLC) model was used to develop learning media, while evaluating user satisfaction with multimedia elements used models from research [13], [14]. Figure 1 illustrates a research framework consisting of three phases: preliminary analysis, application of the MDLC model, and evaluation.

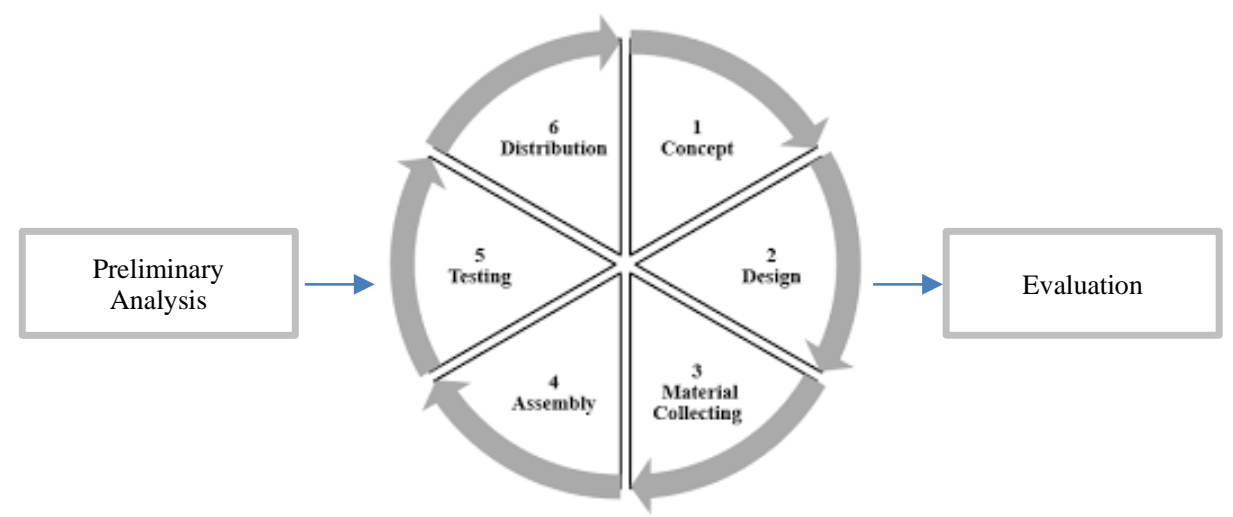

Figure 1. Research Framework with MDLC Model

a. Concept: Who are the users of this learning media? At this stage, the determination is made by deciding students and lecturers are the users. It was obtained from the survey results using interview and questionnaire methods given to students and lecturers of Diploma of Telecommunications Technology. In addition, this stage also determined the software and hardware needed in making interactive learning media.

b. Design: Design of the user interface, software or program, and material requirements for the program. It was created using Adobe Flash Professional CS6 software.

c. Material Collecting: Collection of materials including icons, images, audio, and video. The stage can be done in parallel with the assembly stage.

d. Assembly: At this stage, the storyboard, navigation structure, and flow chart are created.

e. Testing: The testing stage is testing the previous manufacture to see whether any features that do not work properly. If they do, then an improvement program will be conducted. Alpha testing is conducted in the manufacturer's environment. It aims to obtain feedback from the users (the lecturers and students who are currently and have taken courses in cellular communication systems in the Diploma of Telecommunications Technology study program).

f. Distribution: Learning media is stored in a storage medium and is ready to be distributed to the lecturers and the students of the cellular communication system class.

Figure 2 below shows the navigation flow of interactive learning media in the subject of the call processing and optimization of cellular networks. 


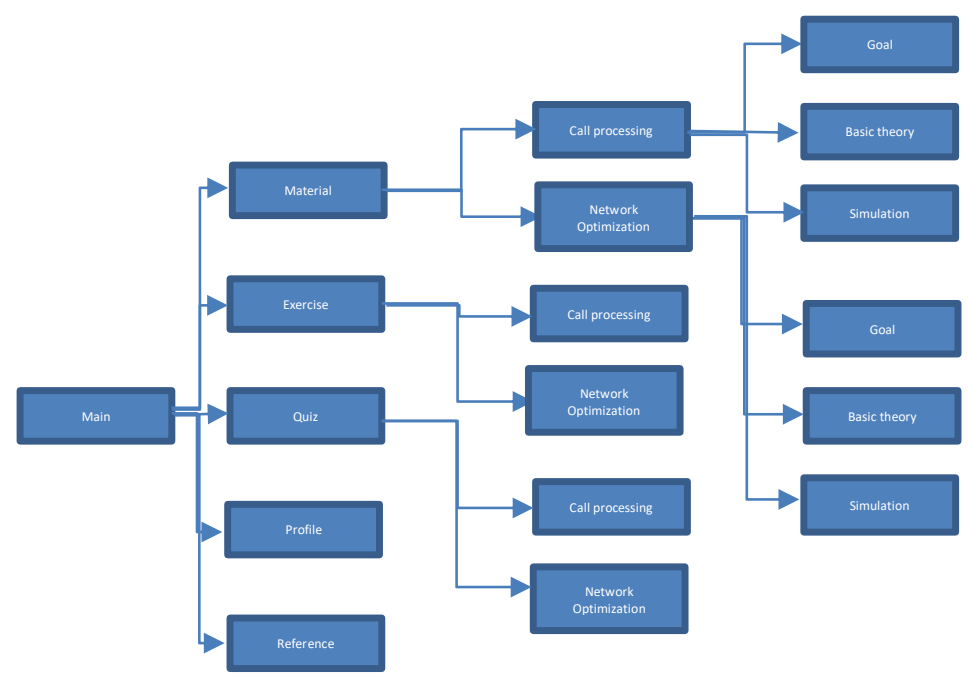

Figure 2. Navigation Flow Design of Interactive Learning Media of Cellular Communication Systems

This learning media consists of several menus: the Main Menu, which displays sub-menus in the learning media such as the Material, Exercise, Quiz, Profile, and Reference sub-menus. When the material button is clicked, the Call Processing material and Network Optimization material sub-menu will appear, then the user selects the material for call processing or network optimization. On the Call Processing material sub menu, there are three main buttons: Goal, Basic Theory and Simulation, as well as the Network Optimization sub-menu item. Meanwhile, when the user intends to do a question exercise, press the Exercise button in the main menu. Finally, in the question exercise menu, the user selects the material to be done.

This exercise is in the form of multiple-choice, and the user should answer correctly to proceed with the afterward problem. This learning media also provides a Quiz menu. On the start page of the quiz, the user will read the quiz operation rules and enter the full name. In this quiz sub-menu, the type of questions is randomly delivered, and after finishing working on the questions, the quiz results will appear. In addition, this interactive learning media provides a profile menu that contains learning media developers. If the user intends to see the reference material presented in the learning media, the user presses the Reference menu button.

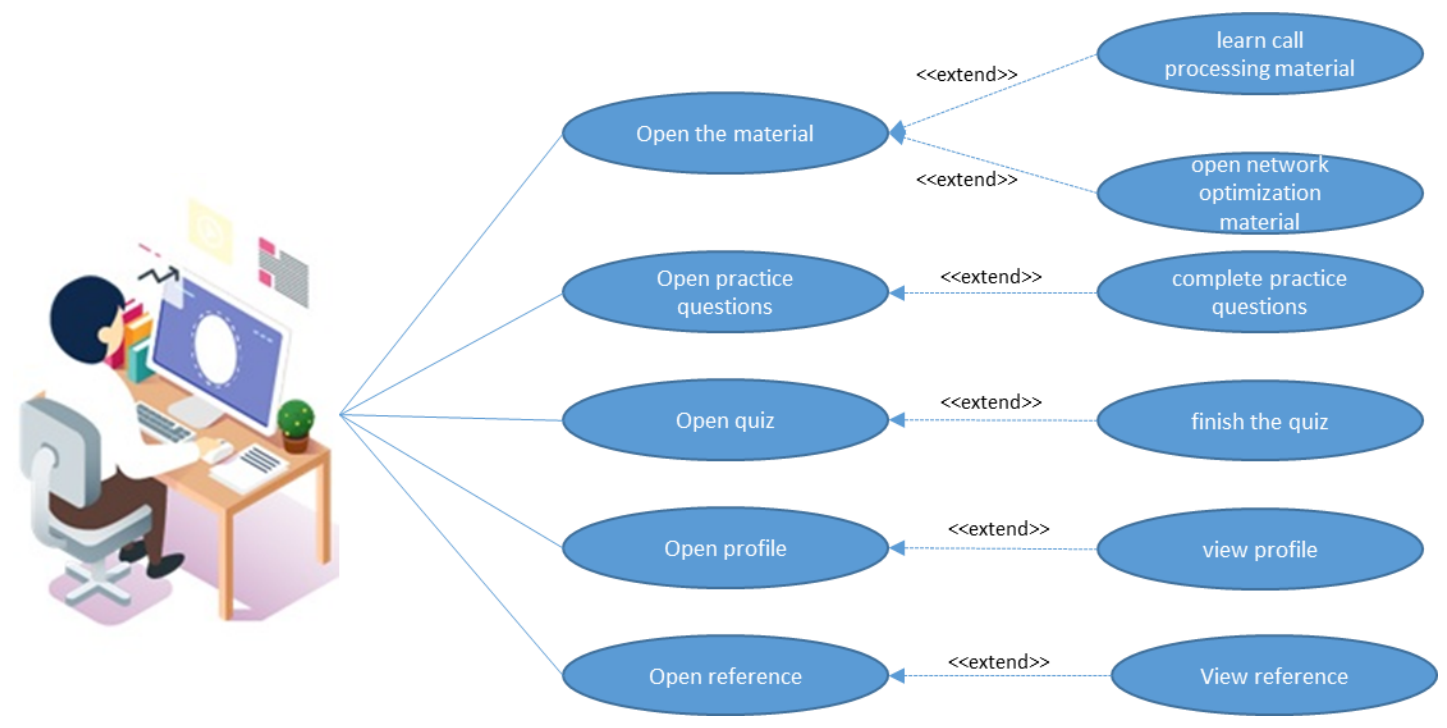

Figure 3. Use Case Diagram

Figure 3 shows the use case diagram in the design of learning media [15]. In this application, the students who act as actors look at the main menu. The main menu is divided into five sub-menus: material, practice questions, quizzes, profiles, and references. In the material sub menu there are two more sub-menus: call processing and network optimization. The students can also choose to do exercises, for instance, call processing or network optimization. In addition, they can also choose to do call processing quiz and network optimization. After finishing working on the quiz, the score appears. Furthermore, the students have access to see the references used in this material. 


\section{RESULTS AND DISCUSSION}

This interactive learning media is ready to be used to support learning cellular communication systems by using Adobe Flash Player.

\subsection{Displays of interactive learning media}

Figures 3 - 15 below show the results of interactive learning media designs for cellular communication systems courses.

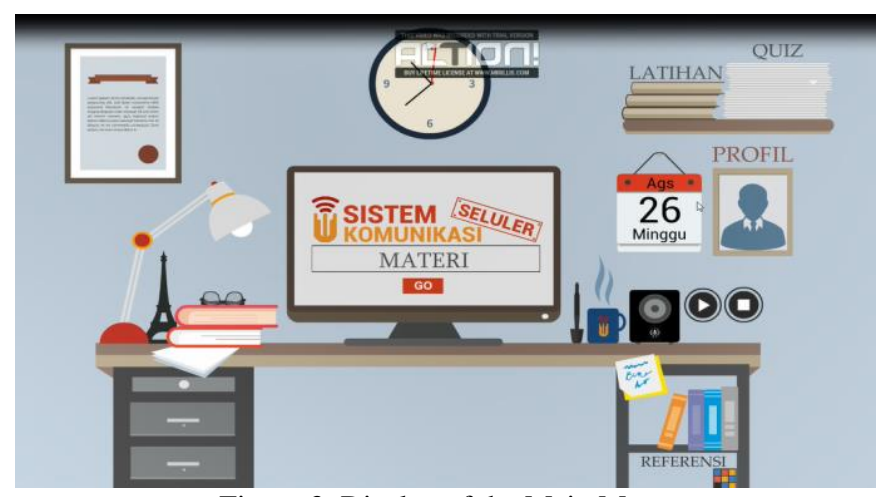

Figure 3. Display of the Main Menu

Figure 3 shows the main menu display consisting of several menus. The menu includes exercises, quizzes, profiles, and references. The display appears at the beginning when the program is run. In addition, it also provides clock, calendar animation, and music that serves to give more the aesthetic value of the main menu display.

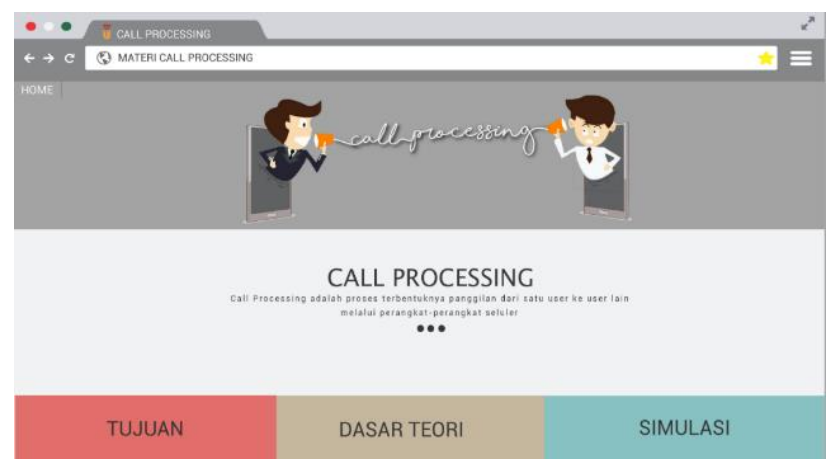

Figure 4. Call Processing Menu Display

Figure 4 shows the menu display of call processing material. In this section, there are three sub-menus: objectives, basic theory, and simulation.

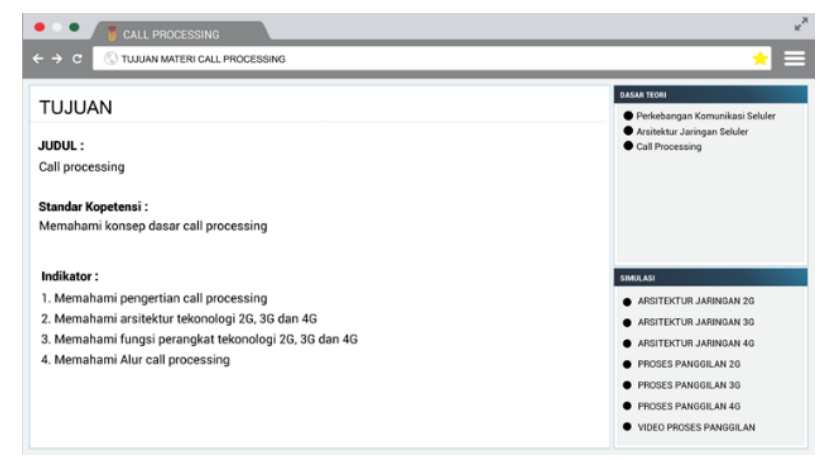

Figure 5. Sub Menu Objectives Topics Call Processing Display

Figure 5 shows the objectives page display of the call processing material containing Title, Competency Standards, and Success Learning Indicators. The page consists of the basic call processing theory button. If it is clicked to the desired material, it shows the call processing simulation button, the return button to the menu page of the call processing material, and the main menu.

Interactive Learning Media for Cellular Communication Systems using the Multimedia Development 


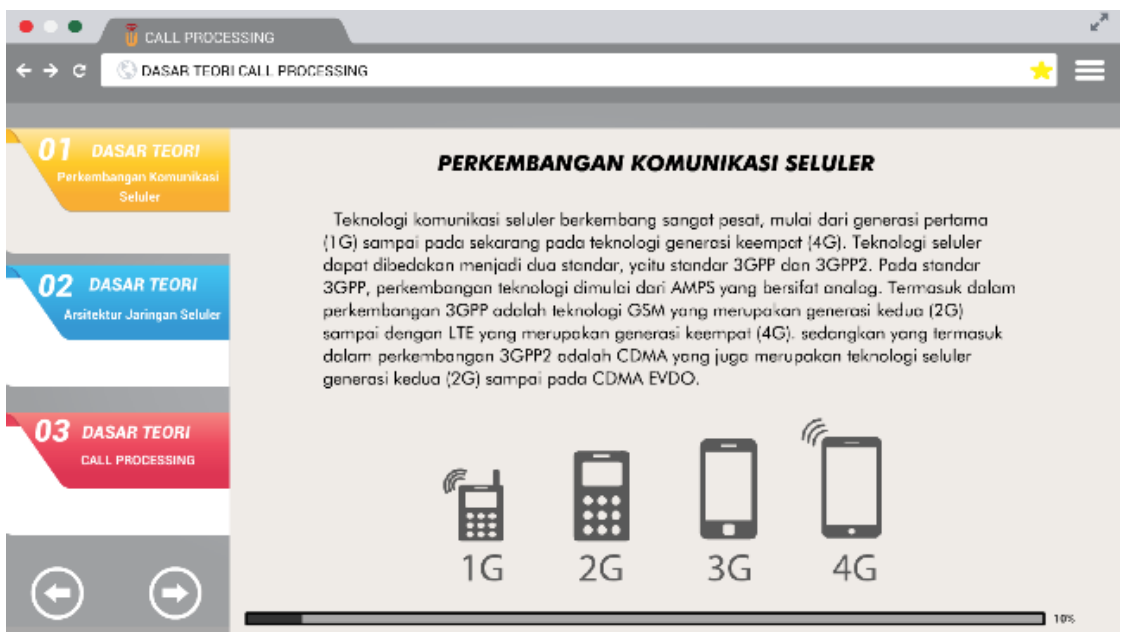

Figure 6. Basic Menu Display of Main Theory of Call Processing

Figure 6 shows the basic page display of call processing theory, which contains theories related to call processing, such as the development of cellular communication, cellular network architecture, and call processing. On the page, there are several buttons, namely the before button and the next button, which function to see the previous or next page presented in this interactive learning media. This page also provides a button to return to the call processing material page and a button to return to the main menu.

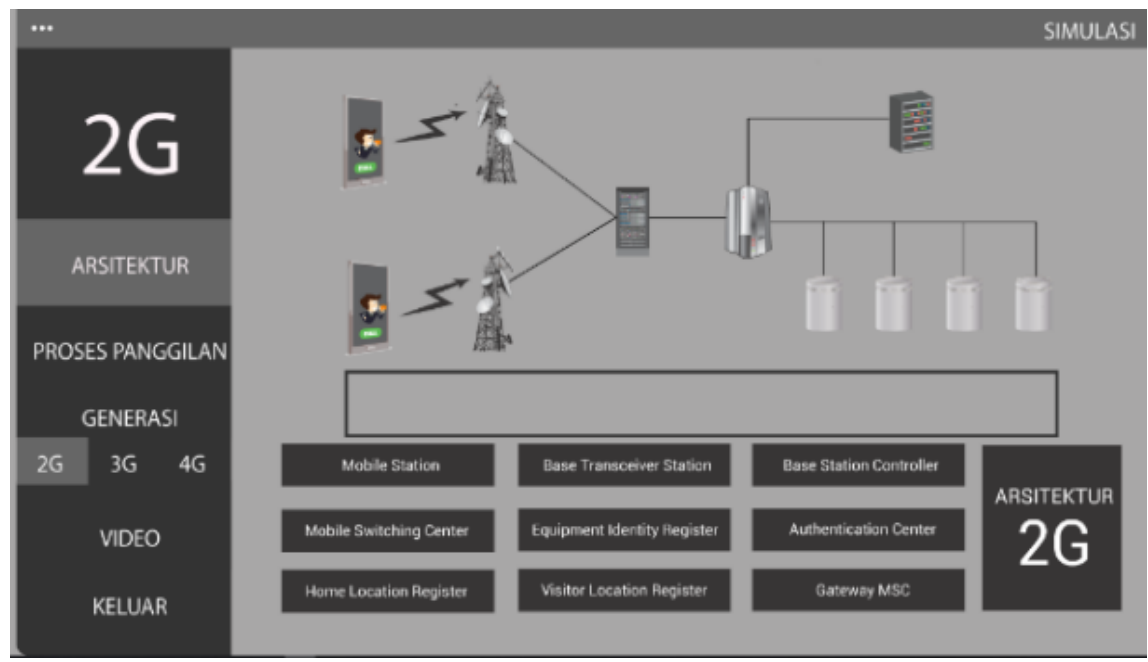

Figure 7. Simulation Menu Sub Menu Call Processing Display

Figure 7 shows the page of call processing simulation that consists of an architecture menu,- a call process for each generation, $2 \mathrm{G}, 3 \mathrm{G}$, and $4 \mathrm{G}$, and a simulation video.

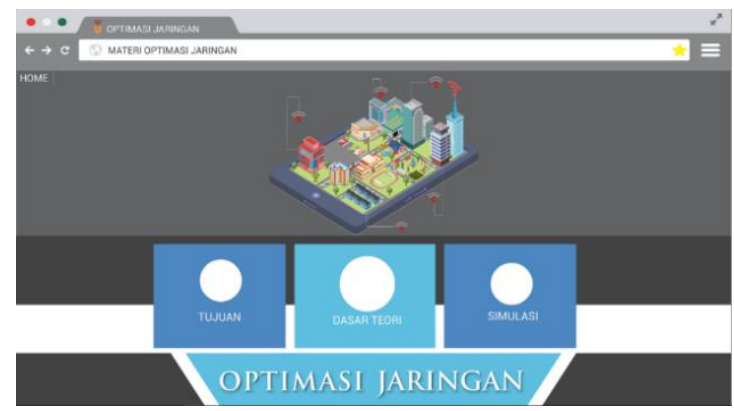

Figure 8. Menu Display Network Optimization

Figure 8 shows the display of Network Optimization material, which consists of several buttons: (1) the goal button is to go to the learning goal page of network optimization, (2) the basic theory is to go to the basic page of network optimization theory, (3) simulation is to go to the simulation page of network optimization, and (4) the back button to sub-menu material and back button to the main menu. 


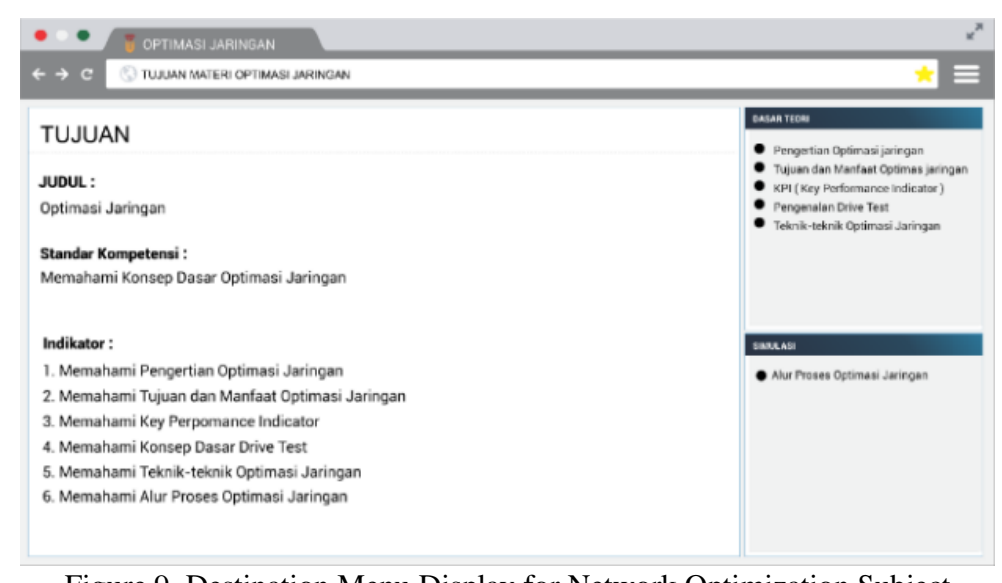

Figure 9. Destination Menu Display for Network Optimization Subject

Figure 9 shows the learning objectives page of network optimization material. It provides titles, competency standards, and indicators of learning outcomes. On this page, there are several buttons provided: (1) the basic theory of network optimization when it is clicked then it will go to the basic theory of the desired material, (2) the network optimization simulation button, (3) the back button to the network optimization material menu page, and (4) the back button to the main menu.

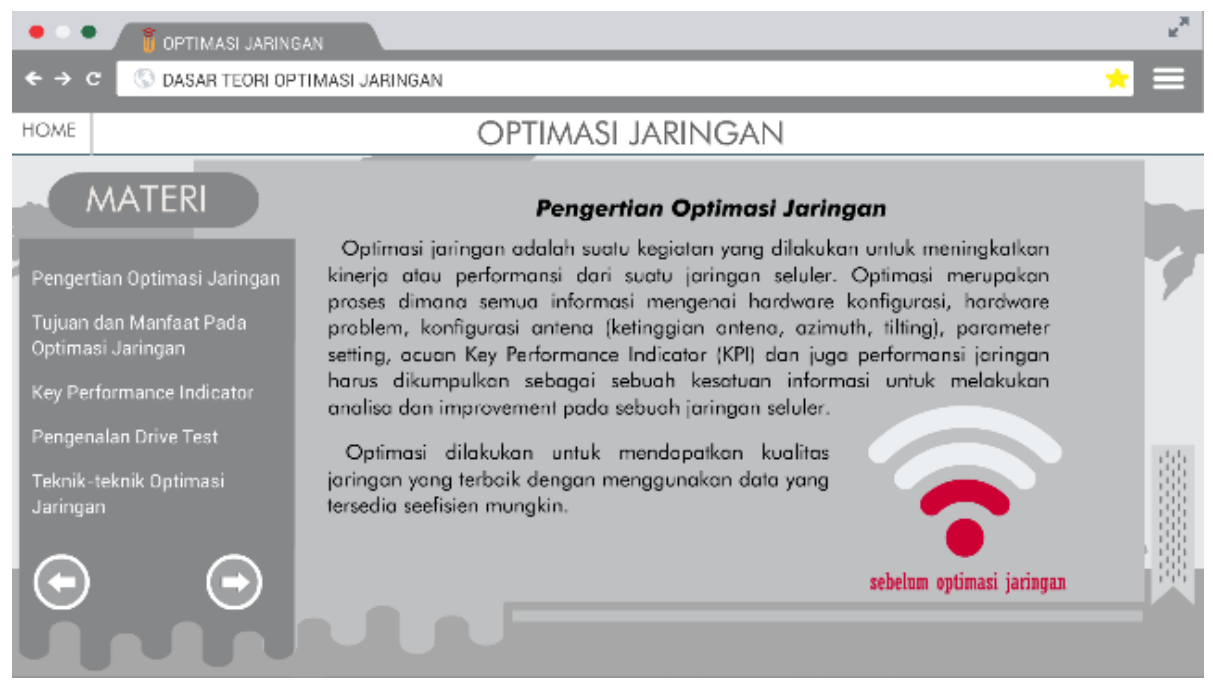

Figure 10. Basic Menu Display Principal Theory of Network Optimization

Figure 10 shows the display of the basic menu of network optimization theory. This page provides several sub-menus, such as understanding network optimization, learning objectives and benefits, key performance indicators, introduction of drive tests, and network optimization techniques. It also serves with buttons before and next to see the previous or next page from the theory presented.

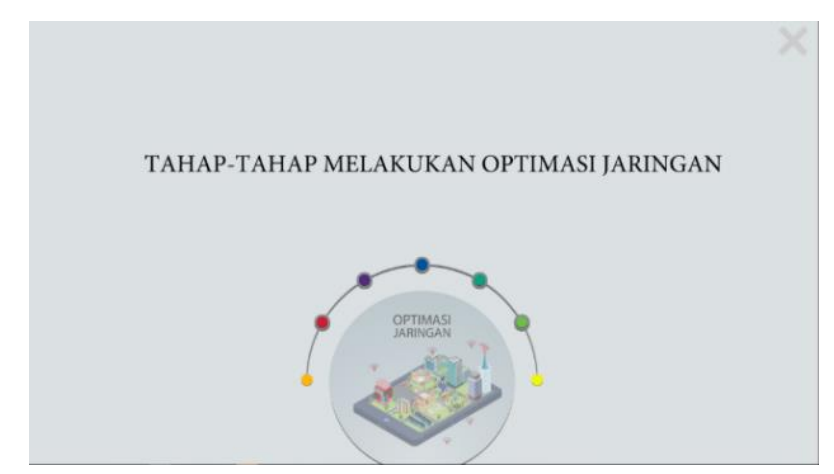

Figure 11. Menu Simulation Network Optimization Subject Display

Interactive Learning Media for Cellular Communication Systems using the Multimedia Development 


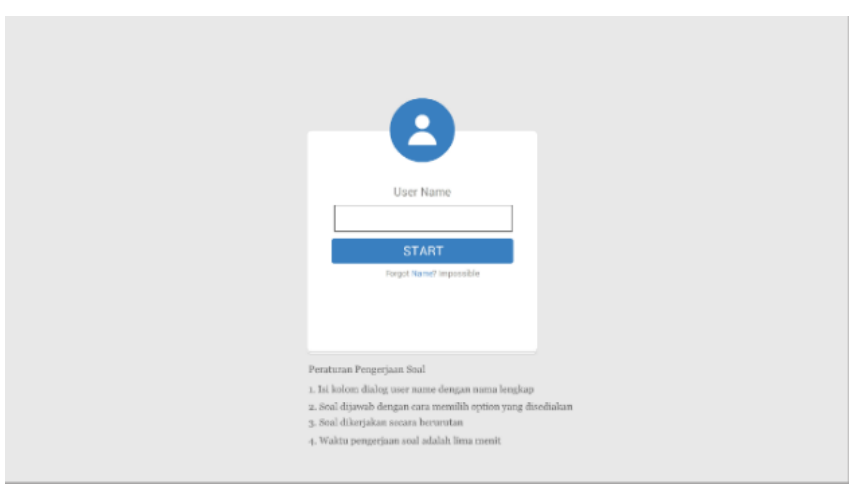

Figure 12. The Start Quiz Page Display

Figure 11 shows the display of the network optimization simulation page containing the stages of performing network optimization. This page provides a play animation button that functions to run the network optimization process animation and a back button that functions to return to the network optimization material menu.

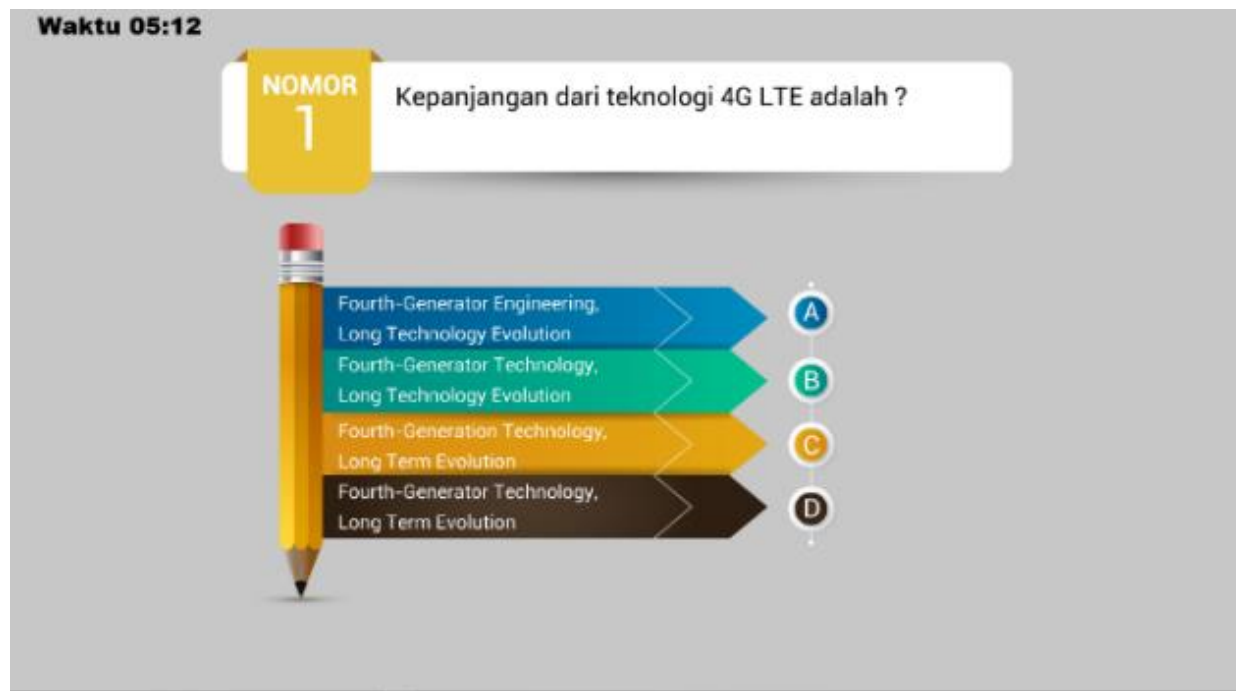

Figure 13. Display of Quiz Problem Pages

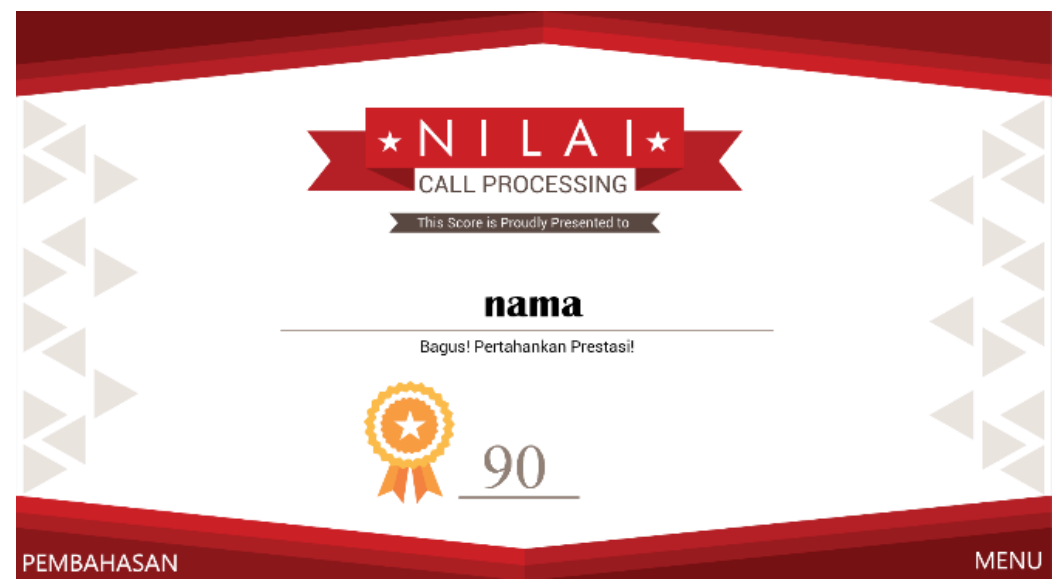

Figure 14. Display of Quiz Value

Figure 14 shows the initial menu display to start the quiz. This page provides a "Start" button and a dialog field to enter the user's name. The users are required to enter a name to enter the quiz questions page as shown in Figure 13. On this page, there are multiple-choice questions and have a time span of work. When the user has finished answering all the quiz questions, the last page will display the value page. For the score obtained, it can be seen in Figure 14. 


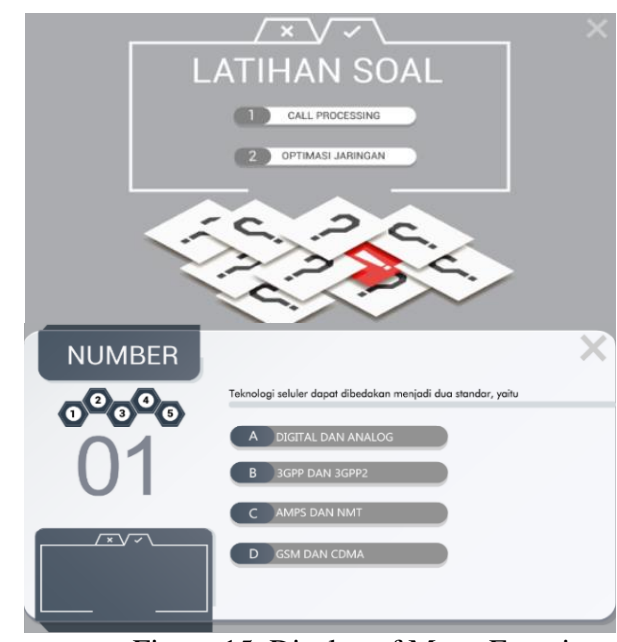

Figure 15. Display of Menu Exercises

Figure 15 shows the display of the practice page. This page provides the choice of practice questions, namely, call processing and network optimization. In addition, it also serves the reference menu and an interactive learning media developer profile that has been designed.

\subsection{Testing of interactive learning media}

After completing the design stage and realization of interactive learning media, the next stage is testing and evaluation. In this study, there are three types of testing: functionality testing, user satisfaction testing on the use of multimedia elements, and quantitative testing.

\begin{tabular}{ccc}
\multicolumn{3}{c}{ Table 1. Functionality Testing } \\
\hline Number & Menu & Success (\%) \\
\hline 1 & Main & 100 \\
2 & Call processing & 100 \\
& subject & \\
3 & Network & 100 \\
& optimization & \\
& subject \\
4 & Exercises & 100 \\
5 & Quiz & 100 \\
6 & Profile & 100 \\
\hline
\end{tabular}

Table 1 shows the functionality testing result of interactive learning media. Based on the testing results, it can be concluded that all menus have worked as expected and are $100 \%$ free of syntax errors.

In addition to the functionality testing, user satisfaction was also tested to use multimedia elements in interactive learning media. The test was carried out by giving questionnaires to 52 respondents. It applied the Mean Opinion Score (MOS) scheme, where the respondents rate was on a scale of $1-5$,- a weighting value of 5 with a strongly agreed statement, a weighting value of 4 with an agreement, a weighting value of 3 with a neutral statement, a weighting value of 2 with a disagreement statement, and a value weight 1 with strongly disagreement remark.

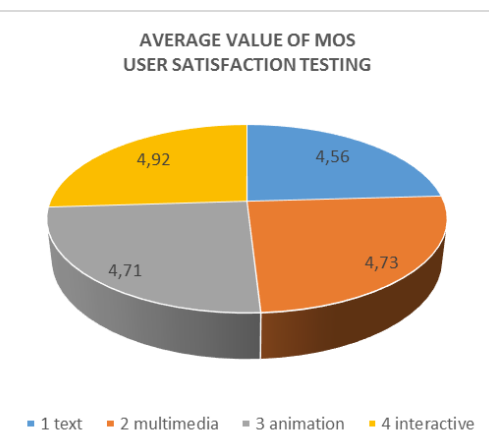

Figure 16. Testing of User Satisfaction of Multimedia Elements

Interactive Learning Media for Cellular Communication Systems using the Multimedia Development 
Based on the testing results of user satisfaction with multimedia elements. As seen in Figure 16, it obtained an average value of 4.92. It shows that the learning media has been going very well. The average value of interactive learning media for courses in cellular communication systems reached 4.73 , which means it is included in the excellent category and is ready to be applied in the cellular communication system class.

The third test is quantitative testing to see Quiz results after students learn to use the interactive learning media. The test was conducted on 20 students. Figure 17 follows the quantitative testing data.

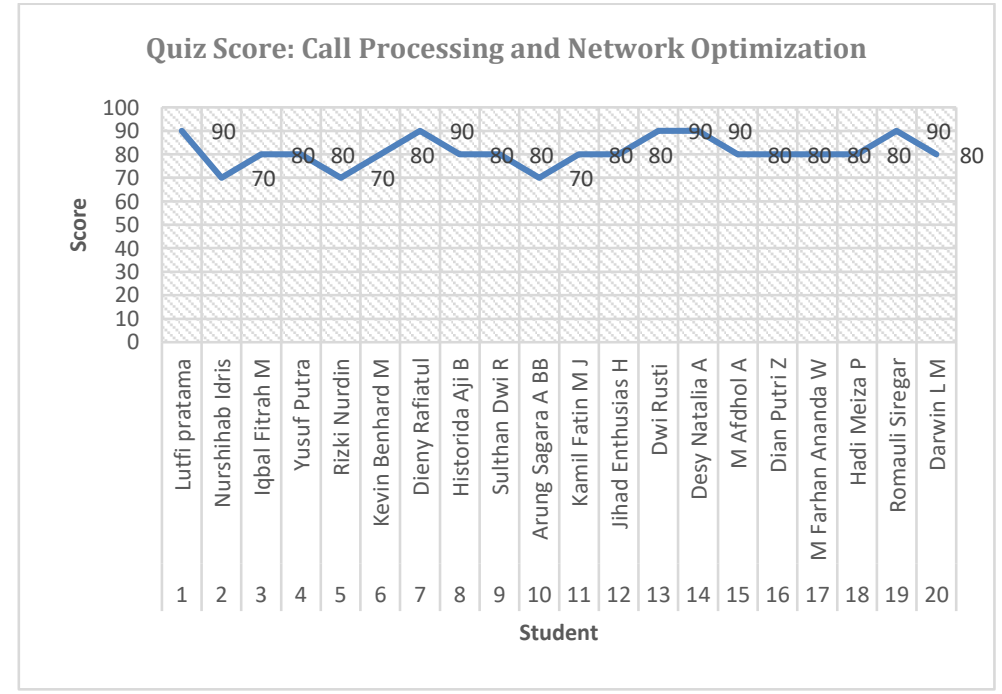

Figure 17. Quantitative Testing

Based on the quantitative test data, it revealed the improvement of student learning. The outcomes showed a range of values from 70 to 90 and an average of 81 . The value result is included in the excellent category, which means a $66 \%$ increased from previous years, which did not implement this interactive learning media.

\section{CONCLUSION}

Based on functionality testing, this learning media has worked $100 \%$ according to design and specifications. Meanwhile, based on the testing results of user satisfaction with multimedia elements, it obtained an average value of MOS was 4.73 from a scale of 1 to 5, and specifically for the interactive elements obtained an average value of 4.92 , which means the display on the learning media is categorized as great and interactive. Furthermore, for the quantitative testing, the average value was 81 , which means the built learning media can increase students' interest which affects the increase in learning outcomes by $66 \%$ from previous years.

\section{REFERENCES}

[1] Z. A. Muriyatmoko, Dihin, Pradhana, Faisal Reza, Musyafa', "Durus Al-Lughah Gontoty: Arabic Learning Media For Beginners Using The Direct Method," J. Teknol. Inf. dan Ilmu Komput., vol. 6, no. 1, pp. 77-84, 2019.

[2] E. Darmanto, Hari, Yulius, Hermawan, Budi, Setyawati, "Chinese Content Management System Application to Support the Hanyu Shuiping Kaoshi Exam,” J. Teknol. Inf. dan Ilmu Komput., vol. 6, no. 1, pp. 9-16, 2019.

[3] Ambar Sri Lestari, "Development of Interactive E-Learning Using Multimedia Design Model," Adv. Sci. Lett., vol. 23, no. 2, pp. 785-789, 2017.

[4] Ade Sri Madona, "Design of Interactive Multimedia Based IPS Learning Module Using CTL Approach Based on Student Tendency Response in the Use of Learning Module in Grade IV," in 1st International Conference on Educational Sciences, 2017.

[5] M. Mustika, Sugara, Adhy Eka Prasetya, Pratiwi, "Development of Interactive Learning Media Using the Multimedia Development Life Cycle Method,” J. Online Inform., vol. 2, no. 2, pp. 121-126, 2017.

[6] Y. N. Hasnul Fikri, Ade Sri Madona, "Development of Instructional Media for Teaching Bahasa Indonesia through Interactive Multimedia Based on Response of Trends in Using Instructional Media by the Students and Teachers during the Learning Process," in 1st International Conference on Educational Sciences, 2017.

[7] G. M. M. R. Sauman Chu, "Interactive Learning for Graphic Design Foundations," E-Learning Digit. Media, vol. 9, no. 4, pp. 345-355, 2012.

[8] John Potter, "Problematising learning in the age of data 'acquisition': issues in research, teaching and learning with digital media and technology," Learn. Media Technol., vol. 43, no. 2, pp. 117-118, 2018.

[9] W. M. Purwati, Yuli, Sagita, Selvi, Utomo, Fandy Setyo, Baihaqi, "Development of Solar Reality-Based Solar Learning Media for Class 6 Elementary School Students With Evaluation of User Satisfaction of Multimedia Elements," J. Teknol. Inf. dan Ilmu Komput., vol. 7, no. 2, pp. 259-266, 2020. 
[10] A. R. Aththibby, "Development of Physics Learning Media Based on Flash Animation for Business and Energy Discussion Topics," J. Pendidik. Fis., vol. 3, no. 2, 2015.

[11] A. Sophan, Kautsar Mochammad, Kurniati, "Interactive Learning by Doing Application Design to Support Programming Language Learning," J. Teknol. Inf. dan Ilmu Komput., vol. 5, no. 2, pp. 163-170, 2018.

[12] S. H. Naufal Irfan Hayanto, "Development of the Science Exercise Application for Elementary Schools with Gamifiaksi and Mersenne Twister," J. Teknol. Inf. dan Ilmu Komput., vol. 7, no. 1, pp. 87-98, 2020.

[13] R. D. Sri Lestari Rahayu, Fujiati, "Educational Games as A learning media of Character Education by Using Multimedia Development Life Cycle (MDLC)," in 2018 6th International Conference on Cyber and IT Service Management (CITSM), 2018.

[14] Minna Koponen, "Reflecting transcultural media life studies from the perspectives of media literacies," Learn. Media Technol., pp. 1-14, 2019.

[15] A. L. D. Wasita Boonsathorn, Danuvasin Charoen, "Leveraging Random Number Generation for Mastery of Learning in Teaching Quantitative Research Courses via an E-Learning Method," E-Learning Digit. Media, vol. 11, no. 3, pp. 231-249, 2014. 